\title{
Determinants of the National Innovation Systems' Competitiveness of the EU Countries and Ukraine in the Conditions of Global Transformations
}

\author{
YULIIA ORLOVSKA ${ }^{1}$ \\ SVITLANA MOROZOVA ${ }^{2}$
}

\begin{abstract}
The paper reviews innovation activity as a key factor in formation of the international competitiveness of countries. The definition of the national innovation system is given. The tendencies of global transformations within the limits of change of technological ways are substantiated. The key imperatives for Ukraine on the way to form an effective national innovation system within the course of European integration are highlighted. The definition of innovative development of economic systems of the EU countries is given. There is noted that the national innovation systems of the EU member states and Ukraine form a dynamic compositional model of innovation centre-periphery. A cluster analysis was conducted with the aim to identify groups of countries with similar characteristics of innovation, which allowed to identify 6 clusters. The analysis was performed on the basis of the Deductor analytical platform. The initial data were 10 indicators: 1) GDP per capita (Y); 2) exports of goods and services (X1); 3) imports of goods and services (X2); 4) foreign direct investment: inflow (X3); 5) foreign direct investment: outflow (X4); 6) R\&D expenses,\% of GDP (X5); 7) applications for residents' patents (X6);8) share of high-tech products in total exports\% (X7); 9) applications for trademarks (X8); 10) number of research publications (X9). There was analysed the affiliation of each country to a certain cluster, taking into account the transitions for the period of 2005-2018. With the aim to assess innovation, all countries were divided into three subgroups depending on the affiliation to a particular cluster and the transitions between them: "Innovation Centre" (In-C) "Innovation Province" (In-PR), "Innovation Periphery" (In-PF). Ukraine is in the third subgroup of "Innovation Periphery" with European countries such as Portugal, Greece and Cyprus. The sub-indices of the Global Innovation Index and the European Innovation Scoreboard for the period of 2017-2019 were analysed according to the subgroup countries. The results of the analysis were summarized in a table and they allowed to identify key determinants of innovation activity for each group of countries. It is concluded that the obtained sub-indices have the greatest impact on the overall value of the index and therefore on the level of innovation development and international competitiveness of each subgroup of countries, that is why they are considered key determinants of innovation activity. The obtained results can be the basis for the formation of
\end{abstract}

\footnotetext{
* This article was translated from its original in Ukrainian.

${ }^{1}$ Orlovska Yuliia Valeriivna - Doctor of Economics, Professor, Professor of the Department of International Economics and Public Administration of State Higher Educational Institution "Prydniprovska State Academy of Civil Engineering and Architecture", Editor-in-Chief of the professional scientific journal "Economic Space", Corresponding Member of the International Academy of Engineering (Section of Economics and Management) (since 2015), Academician of Economic Sciences of Ukraine (since 2016), Honored Worker of Education of Ukraine (2018). Sphere of scientific interest: sustainable green development, globalization and European integration, development of regional and local economies, green building economy, international specialization of countries, circular and low-carbon economy.E-mail: juliaorlovska@ pgasa.dp.ua

${ }^{2}$ Morozova Svitlana Anatoliivna - Candidate of Economic Sciences, Associate Professor of the Department of International Economics and Public Administration of State Higher Educational Institution "Prydniprovska State Academy of Civil Engineering and Architecture". Sphere of scientific interest: global determinants of innovative development of European countries. E-mail: morozova.svitlana@pgasa.dp.ua
}

IEP, No. 34 (2021), pp. 52-69

(C) Yuliia Orlovska, Svitlana Morozova, 2021 «All rights reserved»

ISSN 1811-9832/2021/No. 1 (34) 
DETERMINANTS OF THE NATIONAL INNOVATION SYSTEMS' COMPETITIVENESS

OF THE EU COUNTRIES AND UKRAINE IN THE CONDITIONS OF GLOBAL TRANSFORMATIONS

a strategy to increase the competitiveness of Ukraine by strengthening innovation, taking into account the key determinants of innovation in the course of European integration. The guidelines for development for Ukraine are the transition to the subgroup "Innovation Province" and the fourth cluster.

KEY WORDS: national innovation systems, innovation activity, EU, Ukraine, determinants of the innovation activity, international competitiveness, global transformations, cluster analysis, Global Innovation Index, European Innovation Scoreboard.

\section{Introduction}

Today, innovative development is the key to form the international competitiveness of countries. In the 1980s, the concept of the National Innovation System (NIS) appeared, based on the definition that the state, education, science, industry, consumers, and the environment are all elements that determine a country's level of innovation. This theory emphasized the importance of the links between NIS participants and explained their behaviour and importance in achievement of the ultimate goal - economic development, the key point of which is innovation. The problems and peculiarities of the development of the national innovation system are described in the works of many famous scientists, in particular, C. Freeman ${ }^{3}{ }^{4}$, B. Lundvall ${ }^{5}$, R. Nelson ${ }^{6}$, J. Metcalfe ${ }^{7}, A . \mathrm{Hall}^{8}$ and others.

It should be noted that the idea in accordance with which the research (national innovation) system consists of such basic units as the state, universities, industry and non-profit organizations appeared in the 1920s as a result of the growing importance of industrial research. The first attempts to analyse this system were made by J. Bernal ${ }^{9}$ in Great Britain and $\mathrm{V}$. Bush ${ }^{10}$ in the USA. That is to say, national innovation systems (NIS) in their modern sense, as well as a systematic approach to their analysis, began to form long before the appearance of the modern scientific concept and its development in a global competitive environment.

\footnotetext{
${ }^{3}$ Freeman C. Technology and Economic Performance: Lessons from Japan. London : Frances Pinter, 1987. $155 \mathrm{p}$

${ }^{4}$ Freeman $C$. The National System of Innovation in Historical Perspective. Cambridge Journal of Economics. - 1995. Vol. 19. P. 5-24.

${ }_{5}^{5}$ Lundvall B. National Systems of Innovation. Towards a Theory of Innovation and Interactive Learning, London : Pinter Publishers, 1992. 317 p.

${ }^{6}$ Nelson R. National Innovation Systems: A Comparative Analysis. New York : Oxford University Press. 1993.560 p.

${ }^{7}$ Metcalfe J. Evolutionary Economics and Technology Policy. Economic Journal. 1994. Vol. 104. P. 931- 944.

${ }^{8}$ Hall A., Sulaiman R., Clark N., Yoganand B. From measuring impact to learning institutional lessons: An innovation systems perspective on improving the management of international agricultural research. Agricultural Systems. 2003. Vol. 78. P. 213-241.

${ }_{9}$ Bernal J. The Social Function of Science. London : Faber \& Faber. 2010. 530 p.

${ }^{10}$ Bush V. Science - the Endless Frontier. A Report to the President. United States Government Printing Office, Washington, July 1945. URL: https://www.nsf.gov/od/lpa/nsf50/vbush1945.html
} 
In the $21^{\text {st }}$ century the role of innovative development in the world economy and national economic systems is growing significantly, due not only to global crises and the corresponding search for new sources of competitiveness of the world economy, but also to the development of the fourth scientific and technological revolution, "Industry 4.0" and the appearance of signs of transition to the new technological revolution "Industry 5.0", which contribute to a radical rethinking of the role of innovation as a major factor in the development of economic systems, economic growth and increase of competitive advantage.

We should note that under the influence of the third scientific and technological revolution ("Industry 3.0") in the last decades of the $20^{\text {th }}$ century, the following new theories were developed: post-industrial, informational, and "new industrial society", their founders were J. Galbraith, P. Drucker, and M. Castells (see in more detail ${ }^{11}$ ), who consider knowledge as the fundamental of the economic formation and innovation potential.

In modern times, humanity is within the sixth technological mode (2010-2040) ${ }^{12}$, which sets the direction of global transformations and is characterized by the appearance of artificial intelligence, the development of genetic engineering, robotics industry, membrane and quantum technologies, biotechnology, alternative energy, nanotechnology. At the same time, there is a decrease in materials and energy consumption of production, increase of ecological compatibility in relation to the environment and the possibility of development of materials and organisms with predefined properties. Moreover, scientists begin to talk about the seventh mode, which should be marked by the development of cognitive and psychotechnologies, but so far, humanity has not yet reached the required technical and innovative level.

It is obvious that the implementation of technologies of the sixth and even more - seventh - technological modes in production processes will significantly affect the functioning of economic systems of countries, as the transition to a new technological mode of life is accompanied by the creation and deepening of new systems of division of labour, which forms numerous opportunities for various innovations in many aspects of people activity. Therefore, there is growing the importance of research of innovation processes and features of their implementation in the innovation policy of different countries, as well as the research of key determinants of innovative development of NIS in the context of these global transformations.

\footnotetext{
${ }^{11}$ Skalatskyi V. M. Informatsiine suspilstvo: suchasni teorii ta modeli (sotsialno-filosofskyi analiz). 2006. URL: http://disser. com. ua/contents/7365. html7365.html. [In Ukrainian].

12 Glazev S. Yu. Teoriya dolgosrochnogo tehniko-ekonomicheskogo razvitiya. Moskva: VlaDar, 1993. [In Russian].
} 
Despite the fact that innovation processes have been studied at the macro level for over a century, and scientific systems began to form in the $17^{\text {th }}$ century, the world economic literature has not a unified approach to the systematic study of the connection between innovation and its national competitiveness in the conditions of global transformations. That is why the purpose of this paper is to identify key determinants of innovation development, which can form the basis for the formation of international competitiveness of countries.

\section{Imperatives for the formation of an effective NIS of Ukraine}

There are a significant number of approaches to the definition of innovative development in foreign and domestic economic literature, but, basically, it means a consistent trend of economic development, under the influence of which it acquires a new structure and quality, and innovation provides the basis for these trends. That is, the essence of innovative development is its impact on the quality of economic growth, which is determined by knowledge and technology. This process, considering the impact of innovation on modern transformations in the global economy (knowledge is becoming a key productive force of the fifth and sixth technological modes), is irreversible.

For a fuller realization of the potential of innovation, it is important to move from a market concept to an approach based on the "chain of value added creation" proposed by $M$. Porter ${ }^{13}$. An important basis for this concept is the formation of such a policy that significantly reduces transaction costs, as well as improvement of international knowledge and sharing and innovation. Thus, the basis of economic growth are innovative factors, post-industrial technologies and the continuous process of updating knowledge and technology. As a result, a fundamentally new trend in the development of economic systems is formed, namely innovation, in which the main production resource is knowledge, information and intellectual resources, and the subject of new trends are national innovation systems (NIS).

An important task for each country is the formation of a strategy of innovative development, which will help increase its level of international competitiveness and identify development trends in the context of global transformations. The key element of strategies should be the determinants of innovation development, which may be different in particular countries

${ }^{13}$ Porter, M. Mezhdunarodnaia konkurentsyia: konkurentnыe preymushchestva stran. Alpyna Pablysher, 1993. [In Russian]. 
due to different initial conditions and features of the structure and functioning of the economic system.

Today, Ukraine is actively involved in global innovation processes. Given its course towards European integration, an important task is the determination of Ukraine's compliance with the trends of innovative development of the EU countries, as well as the identification of key determinants of innovative development in the "European coordinate system".

In these conditions, the innovative development of economic systems of the EU countries means the mechanism of sustainable functioning of national innovation systems (NIS) of the member countries of the integration association, taking into account the existing (and forming) conditions of economic development in the association and challenges of the global technological environment. This definition provides a framework understanding of the main priorities for construction of the NIS of the countries, which tend to the European integration, including Ukraine.

In our opinion, the main challenges in construction of an effective NIS of Ukraine should be considered the following. Firstly, transformations under the influence of the scientific and technological revolution are becoming one of the specific characteristics of the modern economy in the context of global technological transformations.

Secondly, integration is becoming the dominant trend in economic development in the world, as it includes all subjects operating at different levels of the organization of economic activity, from households to national and supranational associations.

Thirdly, at the present stage of development of the domestic economy, the innovative aspect of development has particular importance, because the asymmetry of innovative development that exists between the world economy, shows low investment attractiveness of Ukraine, contributes to increase in unreasonable transaction costs.

Fourthly, given that the growing number of scientific papers on the identification of determinants of the functioning of innovation systems in the global economy are appeared, as well as the fact that there is no single approach to assess the effectiveness of national innovation systems in world theory and practice there is a need to form the tools of such an assessment based on the realities of the functioning of Ukraine's economy and the formed foreign policy course of its development.

Therefore, an important task is the determination of the role of Ukraine in the EU innovation system and identification of key determinants of innovation development, which should be the basis for the formation of the country's innovation strategy. 


\section{Clusters of EU innovative development: country-based approach}

Modern processes taking place in the innovative development of European countries are connected on the one hand with the regulation of their national innovation systems in the form of a "centre-periphery" model. On the other hand, these processes are developing under the influence of uncertainty and cascades of bifurcations, which due to the increase in the integrity and interconnection of the subjects of the centre-peripheral system lead to substantial changes in the state of each of them. However, these phenomena can not be called contradictory, on the contrary, they are characteristics of the same process - the innovative development of the world economy in the $21^{\text {st }}$ century, based on which successful strategies for innovative development must be formed. Obviously, it is necessary to understand the main drivers of innovatization, the main determinants of innovative development of certain NIS for the formation of such strategies.

NIS the EU member states and Ukraine form a dynamic compositional model of innovative centre-peripherality, in which the movement of countries "to the centre" means the successful innovative development of economic systems and their high competitiveness. In these conditions, it is important to determine the trends of relations in the innovation sphere of EU member states within the model of "centre-periphery". With this aim, the EU states and Ukraine were grouped using the tools of cluster analysis and artificial intelligence, which revealed dynamic changes in the belonging of countries to the particular cluster of innovative development.

The analysis and evaluation was carried out using a system of indicators that determine the conditions and results of innovative development of economic systems, namely: 1) GDP per capita (Y); 2) exports of goods and services (X1); 3) imports of goods and services (X2); 4) foreign direct investment: inflow (FDI inflows) (X3); 5) foreign direct investment: outflow (FDI outflows) (X4); 6) R\&D expenses,\% of GDP (X5); 7) applications for residents' patents $(\mathrm{X} 6) ; 8)$ the share of high-tech products in total exports\% (X7); 9) applications for trademarks (X8); 10) number of research publications (X9).

The Deductor ${ }^{14}$ analytical platform was used to implement the clustering. Because of self-organized learning (without a teacher) of the neural network, all "countries - neural networks" were grouped into 6

${ }^{14}$ World Bank official statistics service. URL: https://data.worldbank.org/ 
clusters. The average values of the 10 output indicators for each cluster are shown in Table 1.

Table 1

AVERAGE INDICATORS OF CLUSTERS OF EUROPEAN COUNTRIES

\begin{tabular}{|c|c|c|c|c|c|c|}
\hline \multirow[b]{2}{*}{ Indicator } & \multicolumn{6}{|c|}{ Cluster } \\
\hline & $\stackrel{\circ}{\stackrel{0}{N}}$ & $\begin{array}{l}\dot{\omega} \\
\stackrel{\omega}{=} \\
i \\
\dot{v}\end{array}$ & 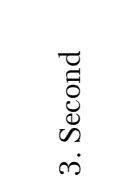 & 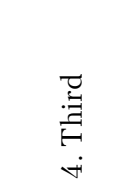 & 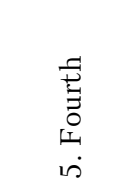 & $\begin{array}{l}\stackrel{F}{ \pm} \\
\dot{D}= \\
0\end{array}$ \\
\hline GDP per capita & 50741 & 38252 & 34459 & 27941 & 23569 & 13310 \\
\hline $\begin{array}{l}\text { Exports of goods and } \\
\text { services }\end{array}$ & 196958 & 1272949 & 235797 & 790694 & 124275 & 59286 \\
\hline $\begin{array}{l}\text { Imports of goods and } \\
\text { services }\end{array}$ & 218171 & 767251 & 313839 & 27541 & 120976 & 65372 \\
\hline FDI inflows, USD, mln & 8168 & 44747 & 22000 & 7466 & 10695 & 4338 \\
\hline FDI outflows, USD, mln & 14425 & 58911 & 21671 & 4820 & 5111 & 1414 \\
\hline R\&D expenses, \% of GDP & 3.00 & 1.70 & 1.63 & 1.64 & 1.61 & 0.71 \\
\hline $\begin{array}{l}\text { Applications for } \\
\text { residents' patents }\end{array}$ & 1818 & 18047 & 673 & 890 & 508 & 871 \\
\hline $\begin{array}{l}\text { Share of high-tech products } \\
\text { in total exports, \% }\end{array}$ & 13.4 & 15.1 & 21.9 & 38.6 & 9.6 & 8.0 \\
\hline Applications for trademarks & 10137 & 59979 & 5170 & 1882 & 12945 & 10294 \\
\hline $\begin{array}{l}\text { Number of research } \\
\text { publications }\end{array}$ & 12963 & 74456 & 8026 & 7530 & 9025 & 6814 \\
\hline
\end{tabular}

Source: calculated by the authors using the Deductor analytical platform according to the data of the World Bank official statistics service ${ }^{15}$

For further detail analysis, the countries were selected according to the location in the clusters, indicating the relevant transitions (Table 2).

\footnotetext{
${ }^{15}$ World Bank official statistics service. URL: https://data.worldbank.org/
} 
DETERMINANTS OF THE NATIONAL INNOVATION SYSTEMS' COMPETITIVENESS

OF THE EU COUNTRIES AND UKRAINE IN THE CONDITIONS OF GLOBAL TRANSFORMATIONS

ATTRIBUTION OF EU COUNTRIES TO IDENTIFIED CLUSTERS

Table 2 OF INNOVATIVE DEVELOPMENT

\begin{tabular}{|c|c|c|}
\hline Cluster & Period, years & County \\
\hline \multirow{4}{*}{ Zero } & $2005-2018$ & $\begin{array}{l}\text { Denmark, } \\
\text { Finland, } \\
\text { Sweden }\end{array}$ \\
\hline & $2012-2018$ & Belgium (transition from the fourth cluster) \\
\hline & $2005-2016$ & Austria \\
\hline & $2017-2018$ & Great Britain (transition from the first cluster) \\
\hline \multirow{3}{*}{ First } & $2005-2018$ & $\begin{array}{l}\text { Germany, } \\
\text { France, } \\
\text { Luxembourg }\end{array}$ \\
\hline & 2005-2016 & $\begin{array}{l}\text { Great Britain, } \\
\text { Spain, } \\
\text { Italy, }\end{array}$ \\
\hline & $2017-2018$ & Austria (transition from zero cluster) \\
\hline \multirow{6}{*}{ Second } & $2005-2018$ & Netherlands \\
\hline & $2007-2018$ & Ireland (transition from the third cluster) \\
\hline & $2005-2014$ & Hungary \\
\hline & 2012 & Czech Republic \\
\hline & 2009 & Greece (transition from the fifth cluster) \\
\hline & $2017-2018$ & Spain, Italy (transition from the first cluster) \\
\hline \multirow{3}{*}{ Third } & $2005-2006$ & Ireland \\
\hline & $2006-2011$ & Cyprus (transition from the fifth cluster) \\
\hline & $2005-2018$ & Malta \\
\hline \multirow{6}{*}{ Fourth } & $2005-2011$ & Belgium \\
\hline & $2009-2018$ & Estonia (transition from the fifth cluster) \\
\hline & $2008-2016$ & Portugal (transition from the fifth cluster) \\
\hline & $\begin{array}{l}2005-2010 \\
2017-2018\end{array}$ & Slovenia (transitions from the fifth cluster) \\
\hline & $2015-2018$ & Hungary (transition from the second cluster) \\
\hline & $\begin{array}{l}2005-2011 \\
2013-2018 \\
\end{array}$ & Czech Republic \\
\hline \multirow{6}{*}{ Fifth } & $2005-2018$ & Bulgaria, Ukraine, Croatia, Romania, Slovakia, Latvia, Lithuania, Poland \\
\hline & $\begin{array}{l}2005-2008 \\
2010-2018 \\
\end{array}$ & Greece \\
\hline & $2005-2008$ & Estonia \\
\hline & $\begin{array}{l}2005,2012- \\
2018\end{array}$ & Cyprus (transition from the third cluster) \\
\hline & $\begin{array}{l}2005-2007 \\
2017-2018 \\
\end{array}$ & Portugal (transition-return from the fourth cluster) \\
\hline & $2011-2016$ & Slovenia \\
\hline
\end{tabular}

Source: made by the authors based on the results of cluster analysis 
With the aim to identify the determinants of innovative development of EU countries, they were grouped by the cluster analysis into three subgroups $\mathrm{A}, \mathrm{B}$ and $\mathrm{C}$.

Thus, the analysis in subgroup A "Innovation Centre" (In-C) included countries of zero and first clusters, which did not show any "transitions" between subgroups in the model of innovation centre-periphery, these are countries such as Austria, Denmark, Finland, Sweden and Belgium.

For subgroup B "Innovation Province" (In-PR), which consists of the second, third and fourth clusters, the analysis was performed for two types of countries: those that did not change the leading positions in cluster 2 (the cluster closest to the Centre) and b) those who made "transitions" from subgroup C.

Regarding subgroup C "Innovation Periphery" (In-PF) (all countries of Cluster 5), the analysis involved countries that have made a regressive "transition from the centre" (from the subgroup In-PR) - Greece and Cyprus, as well as Ukraine as the last in the international rankings of innovative development (for a certain group of countries "EU $28+1 "$ ).

Such grouping during the analysis will allow, on the one hand, to identify the success determinants of innovatization of economic systems of EU countries (for the countries of the Innovation Centre), on the other determinants of such failure (for countries of the Innovation Periphery) and the main determinants (drivers) of transition "from Periphery to the Province" and further - a potential transition to the Centre.

The determinants of innovation development can be directly identified and characterized by a detailed analysis of the components (sub-indices) of the main indices of innovation competitiveness of countries. Within this paper, a combination of two indices will be used: the Global Innovation Index (GII) ${ }^{16}$ and the European Innovation Scoreboard (EIS) ${ }^{17}$. In our opinion, such a combination of indices characterizes the NIS of a country both in absolute values of the world GII rating (i.e., the actual competitive position) and in relative values of deviation from the average level of innovation development (EIS), which demonstrate the potential for future global competitive change of NIS positions of the country (for better or worse).

The GII (Global Innovation Index) includes 2 subgroups of indicators: those that measure innovation input and those that evaluate innovation output. In turn, the first group includes sub-indices: 1) institutions; 2) human capital and research; 3) infrastructure; 4) market indicators; 5) business experience. The second group of indicators includes sub-indices: 6) knowledge and results of scientific research; 7) creativity. Each of the

\footnotetext{
${ }^{16}$ The Global Innovation Index. URL: https://www.globalinnovationindex.org/Home

17 European Innovation Scoreboard. URL: https://ec.europa.eu/growth/industry/policy/innovation/ scoreboards_en
} 
sub-indices also has a number of indicators in its structure. The total amount of analytical source data included for analysis and calculation of the index is 80 units.

The Innovation Index of the European Innovation Scoreboard (EIS) reflects the main indicators for assessing the effectiveness of the national innovation system. The EU Innovation Scoreboard includes data on EU member states, EU candidate countries and some other countries. It is calculated (generalized) using ten sub-indices to four groups that characterize different aspects of innovation development. These are the subindices of the group "Framework conditions" (the main factors of innovation): 1) human resources; 2) attractiveness of research systems; 3) a favourable environment for innovation; sub-indices of the group "Investments" (public and private investments in innovations): 4) financing and support (innovations); 5) investments of companies; sub-indices of the group "Innovation activity" (at the firm level): 6) innovators; 7) communications and entrepreneurship; 8) intellectual assets; and subindexes of the group "Influence", i.e. the impact of innovation activities of companies: 9) the impact on employment; 10) impact on sales (trade).

In the process of analysis, selected countries were evaluated by the positions in the ranking of indices for the period of 2017-2019. Accordingly, those sub-indices for which countries held leading positions will be determinants of innovation and will form the basis for increase of international competitiveness.

\section{Innovation "centre", "province" and "periphery" in the EU: determinants of innovative development}

An analysis of indices was conducted for each subgroup of countries, which allowed to identify the most influential factors on the innovation activities of the NIS of the EU countries and Ukraine. The results of the analysis were summarized in a table highlighting the most influential subindices for each subgroup of countries.

\section{Subgroup A "Innovation Centre, In-C"}

For each of the countries, the most successful indicators that provided a high actual competitive position (i.e., the value of the GII index) were different components of the index. For Denmark, which ranked $7^{\text {th }}$ place in the world, the largest contribution to the overall ranking is made by the sub-index "Human Capital and Research" (Table 3). The same figure is dominant for Austria (21 st place), and for Belgium (23 $3^{\text {rd }}$ place) and Finland ( $6^{\text {th }}$ place in the world according to the GII index). For Sweden ( $2^{\text {nd }}$ in the 
world), the largest contribution to the overall ranking is made by the subindices "Knowledge and Research Results" and "Infrastructure". The subindex "Institutions" was the most important for Finland.

Table 3

\begin{abstract}
DETERMINANTS OF INNOVATIVE DEVELOPMENT OF THE COUNTRIES OF THE SUBGROUP "INNOVATION CENTRE" IN THE COORDINATES OF THE GLOBAL INDEX OF INNOVATIONS GII
\end{abstract}

\begin{tabular}{|c|c|c|c|c|c|}
\hline & \multirow[t]{2}{*}{ GII index sub-indexes } & \multicolumn{3}{|c|}{$\begin{array}{l}\text { Average value for the countries- } \\
\text { representatives of the "Innovation } \\
\text { Centre" }\end{array}$} & \multirow[t]{2}{*}{$\begin{array}{l}\text { For which country is the } \\
\text { most important }\end{array}$} \\
\hline & & 2017 & 2018 & 2019 & \\
\hline \multirow{5}{*}{ 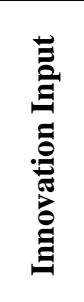 } & Institutions & 12 & 11 & 11 & Finland \\
\hline & $\begin{array}{l}\text { Human capital and } \\
\text { research }\end{array}$ & 5 & 8 & 8 & $\begin{array}{l}\text { Austria, Belgium, } \\
\text { Finland, Denmark }\end{array}$ \\
\hline & Infrastructure & 15 & 15 & 13 & Sweden \\
\hline & Market indicators & 20 & 22 & 26 & \\
\hline & Business experience & 13 & 12 & 10 & \\
\hline \multirow{2}{*}{ 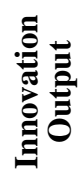 } & $\begin{array}{l}\text { Knowledge and results of } \\
\text { scientific research }\end{array}$ & 17 & 16 & 14 & Sweden \\
\hline & Creativity & 15 & 15 & 18 & \\
\hline
\end{tabular}

Source: made by the authors according to the data of The Global Innovation Index $2017^{18}$, The Global Innovation Index $2018^{19}$, The Global Innovation Index $2019^{20}$

Thus, the determinants of successful innovation development in the group of the Centre can be considered the development of institutions that ensure the innovative development of NIS and the quality of human capital and research in innovation processes (high importance is evidenced by high values of ranking places). "Knowledge and Results of Scientific Research" and "Infrastructure" should also be considered essential components of the success of NIS development of subgroup A countries ("Innovation Centre").

There were also different components of the EIS index for each of the countries of this subgroup, which are the most indicative indicators of

${ }^{18}$ The Global Innovation Index 2017: Innovation feeding the world. Ithaca, Fontainebleau and Geneva: Cornell University, INSEAD and WIPO, 2017. URL: https://www.wipo.int/edocs/pubdocs/en/wipo_pub_gii_2017.pdf

${ }^{19}$ The Global Innovation Index 2018: Energizing the world with innovation. Ithaca, Fontainebleau and Geneva: Cornell University, INSEAD and WIPO, 2018. URL: https://www.wipo.int/edocs/pubdocs/ en/wipo_pub_gii_2018.pdf

20 The Global Innovation Index 2019: Creating healthy lives - the future of medical innovation. Ithaca, Fontainebleau and Geneva: Cornell University, INSEAD and WIPO, 2019. URL: https://www.wipo.int/ edocs/pubdocs/en/wipo_pub_gii_2019.pdf 
"deviation from the EU average" value of innovation, i.e. the formation of potential for future change in the global competitive position of "EU $28+1$ ". For Denmark, which according to the EIS report for 2019 took $3^{\text {rd }}$ place among EU countries, the largest contribution to the overall ranking is made by the sub-index "Favourable Environment for Innovation" (Table 4). The same figure is dominant for both Finland ( $2^{\text {nd }}$ place $)$ and Sweden $\left(1^{\text {st }}\right.$ place among EU countries). For Austria ( $9^{\text {th }}$ among EU countries), the sub-indices "Communications and Entrepreneurship" and "Attractiveness of Research Systems" make the largest contribution to the overall ranking. The sub-index "Attractiveness of Research Systems" was also the most important for Belgium ( $6^{\text {th }}$ place among the EU countries according to the EIS index).

Table 4

\section{DETERMINANTS OF INNOVATIVE DEVELOPMENT OF THE COUNTRIES OF THE SUBGROUP "INNOVATION CENTRE" IN THE COORDINATES OF THE EUROPEAN INNOVATION SCOREBOARD EIS}

\begin{tabular}{|l|c|c|c|c|}
\hline \multirow{2}{*}{ GII index sub-indexes } & \multicolumn{3}{|c|}{$\begin{array}{c}\text { Average value for the countries- } \\
\text { representatives of the } \\
\text { "Innovation Centre" }\end{array}$} & $\begin{array}{c}\text { For which country is the } \\
\text { most important }\end{array}$ \\
\cline { 2 - 5 } & $\mathbf{2 0 1 7}$ & $\mathbf{2 0 1 8}$ & $\mathbf{2 0 1 9}$ & \\
\hline Impact on sales & 80 & 81 & 89 & \\
\hline Impact on employment & 96 & 92 & 95 & \\
\hline Intellectual assets & 129 & 141 & 138 & Austria \\
\hline $\begin{array}{l}\text { Communications and } \\
\text { Entrepreneurship }\end{array}$ & 129 & 141 & 158 & \\
\hline Innovators & 118 & 117 & 123 & \\
\hline Company investments & 150 & 149 & 142 & \\
\hline Funding and support & 109 & 111 & 114 & Denmark, Finland, \\
\hline $\begin{array}{l}\text { Favourable environment for } \\
\text { innovation }\end{array}$ & 179 & 205 & 228 & Sweden \\
\hline Attractiveness of research systems & 179 & 182 & 168 & Belgium, Austria \\
\hline Human resources & 183 & 179 & 180 & \\
\hline The total value of the EIS index & $\mathbf{1 3 1}$ & $\mathbf{1 3 4}$ & $\mathbf{1 3 7}$ & \\
\hline
\end{tabular}

Source: made by the authors according to the European Innovation Scoreboard 2017 ${ }^{21}$, European Innovation Scoreboard $2018^{22}$, European Innovation Scoreboard $2019^{23}$

\footnotetext{
${ }^{21}$ European Innovation Scoreboard 2017. European Comission, 2017. URL: https://ec.europa.eu/docsroom/ documents/24829

22 European Innovation Scoreboard 2018. European Comission, 2018. URL: https://op.europa.eu/en/ publication-detail/-/publication/8e458033-74fc-11e8-9483-01aa75ed71a1/language-en/format-PDF/source-99539237

23 European Innovation Scoreboard 2019. European Comission, 2019. URL: https://ec.europa.eu/ docsroom/documents/38781
} 
It can be affirmed that the countries of the "Innovation Centre" use all three main factors of innovation (in the gradation of the EIS index), namely: attractiveness of research systems, favourable environment for innovation and human resources. Innovative leadership is also supported by the innovative activity of firms, primarily through the sub-index of connections and intellectual assets of firms. It is obvious that the support of the "Framework Conditions" (factors of innovation) and innovation activity of firms at the appropriate level are determinants of success (innovation leadership) of the countries of the Innovation Centre.

\section{Subgroup B "Innovation Province, In-PR"}

In this subgroup, the most successful indicators that provided a high actual competitive position (i.e., the value of the GII index) were different components of the index. For Ireland, which ranked $12^{\text {th }}$ in the world, the largest contribution to the overall ranking is made by the sub-indices "Infrastructure" and "Knowledge and Results of Scientific Research" (Table 5). The latter indicator is also dominant for the Netherlands ( $4^{\text {th }}$ place) together with the "Creativity" indicator. The "Creativity" sub-index makes the largest contribution to the overall ranking of Estonia (24 ${ }^{\text {th }}$ in the world) and Slovenia ( $31^{\text {st }}$ in the world according to the GII index).

DETERMINANTS OF INNOVATIVE DEVELOPMENT OF COUNTRIES OF THE SUBGROUP "INNOVATION PROVINCE" IN THE COORDINATES OF THE GLOBAL INNOVATION INDEX GII

\begin{tabular}{|c|c|c|c|c|c|}
\hline \multicolumn{2}{|r|}{ GII index sub-indexes } & \multicolumn{3}{|c|}{$\begin{array}{l}\text { Average value for the countries- } \\
\text { representatives of the "Innovation } \\
\text { Centre" }\end{array}$} & \multirow[t]{3}{*}{$\begin{array}{l}\text { For which country is the } \\
\text { most important }\end{array}$} \\
\hline & & 2017 & 2018 & 2019 & \\
\hline \multirow{5}{*}{ 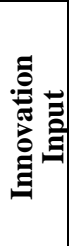 } & Institutions & 16 & 16 & 17 & \\
\hline & Human capital and research & 25 & 23 & 26 & \\
\hline & Infrastructure & 19 & 19 & 18 & Ireland \\
\hline & Market indicators & 38 & 41 & 49 & \\
\hline & Business experience & 18 & 18 & 19 & \\
\hline \multirow{2}{*}{ 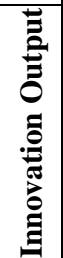 } & $\begin{array}{l}\text { Knowledge and results of } \\
\text { scientific research }\end{array}$ & 19 & 17 & 19 & Ireland, Netherlands \\
\hline & Creativity & 12 & 11 & 14 & $\begin{array}{l}\text { Netherlands, } \\
\text { Estonia, Slovenia }\end{array}$ \\
\hline
\end{tabular}

Source: made by the authors according to the data of the The Global Innovation Index 2017, The Global Innovation Index 2018, The Global Innovation Index 2019 
As for the components of the EIS index, they affect the value of the index itself and its dynamics for different countries to a different extent. Thus, for Ireland, which according to the EIS report for 2019 ranked $10^{\text {th }}$ among EU countries, the largest contribution to the overall ranking is made by three sub-indices: "Human Resources", "Employment Impact" and "Attractiveness of Research Systems" (Table 6).

For the Netherlands (4 ${ }^{\text {th }}$ among EU countries), the sub-indices "Favourable Environment for Innovation" and "Attractiveness of Research Systems" make the largest contribution to the overall ranking. The "Favourable Environment for Innovation" sub-indices, as well as "Human Resources", were the most important for Estonia (12 $2^{\text {th }}$ place among the EU countries according to the EIS index). For Slovenia (15 $15^{\text {th }}$ place among EU countries), the sub-indices "Favourable Environment for Innovation" and "Human Resources" make the largest contribution to the overall ranking.

Table 6

\section{DETERMINANTS OF INNOVATIVE DEVELOPMENT OF THE COUNTRIES OF THE SUBGROUP "INNOVATION PROVINCE" IN THE COORDINATES OF THE EUROPEAN INNOVATION SCOREBOARD}

\begin{tabular}{|l|c|c|c|c|}
\hline \multirow{2}{*}{ GII index sub-indexes } & \multicolumn{2}{c|}{$\begin{array}{c}\text { Average value for the countries- } \\
\text { representatives of the } \\
\text { "Innovation Centre" }\end{array}$} & $\begin{array}{c}\text { For which country is the } \\
\text { most important }\end{array}$ \\
\cline { 2 - 5 } & $\mathbf{2 0 1 7}$ & $\mathbf{2 0 1 8}$ & $\mathbf{2 0 1 9}$ & \\
\hline Impact on sales & 90 & 93 & 91 & \\
\hline Impact on employment & 110 & 108 & 112 & Ireland \\
\hline Intellectual assets & 91 & 92 & 94 & \\
\hline $\begin{array}{l}\text { Communications and } \\
\text { Entrepreneurship }\end{array}$ & 97 & 108 & 115 & \\
\hline Innovators & 89 & 91 & 98 & \\
\hline Company investments & 103 & 100 & 105 & \\
\hline Funding and support & 85 & 89 & 84 & \\
\hline $\begin{array}{l}\text { Favourable environment for } \\
\text { innovation }\end{array}$ & 126 & 150 & 174 & $\begin{array}{c}\text { Netherlands, Estonia, } \\
\text { Slovenia }\end{array}$ \\
\hline Attractiveness of research systems & 135 & 143 & 133 & Ireland, Netherlands \\
\hline Human resources & 156 & 159 & 149 & $\begin{array}{c}\text { Ireland, } \\
\text { Estonia, Slovenia }\end{array}$ \\
\hline The total value of the EIS index & $\mathbf{1 0 6}$ & $\mathbf{1 1 0}$ & $\mathbf{1 1 1}$ & \\
\hline
\end{tabular}

Source: made by the authors according to the European Innovation Scoreboard 2017, European Innovation Scoreboard 2018, European Innovation Scoreboard 2019 


\section{Subgroup C "Innovative Periphery, In-PF"}

For Greece, which ranked $41^{\text {st }}$ in the world in terms of the Global Innovation Index GII, the largest contribution to the overall ranking is made by the sub-index "Human Capital and Research" (Table 7).

The sub-indices "Knowledge and Research Results" and "Market Indicators" make the largest contribution to the overall ranking of Cyprus $\left(28^{\text {th }}\right.$ place in the world). For Portugal, which ranked $32^{\text {nd }}$ in the world in terms of GII, the largest contribution to the overall ranking will be made by the sub-indices "Human Capital and Research" and "Institutions". The sub-index "Knowledge and Results of Scientific Research" makes the largest contribution to the overall rating of Ukraine (43 ${ }^{\text {rd }}$ place in the world).

Estimation of changes in the components of the EIS index. For Greece, which according to the EIS report for 2019 ranked $20^{\text {th }}$ among EU countries, the largest contribution to the overall ranking is made almost by two sub-indices: "Relations and Entrepreneurship" and "Innovators" (Table 8).

Table 7

DETERMINANTS OF INNOVATIVE DEVELOPMENT OF THE COUNTRIES OF THE SUBGROUP "INNOVATIVE PERIPHERY" IN THE COORDINATES OF THE GLOBAL INDEX OF INNOVATION GII

\begin{tabular}{|c|c|c|c|c|c|}
\hline & \multirow[t]{2}{*}{ GII index sub-indexes } & \multicolumn{3}{|c|}{$\begin{array}{l}\text { Average value for the countries- } \\
\text { representatives of the } \\
\text { "Innovation Centre" }\end{array}$} & \multirow[t]{2}{*}{$\begin{array}{l}\text { For which country is the } \\
\text { most important }\end{array}$} \\
\hline & & 2017 & 2018 & 2019 & \\
\hline \multirow{5}{*}{ 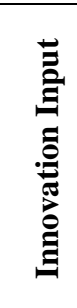 } & Institutions & 34 & 34 & 33 & Portugal \\
\hline & $\begin{array}{l}\text { Human capital and } \\
\text { research }\end{array}$ & 28 & 31 & 31 & $\begin{array}{l}\text { Greece, } \\
\text { Portugal }\end{array}$ \\
\hline & Infrastructure & 52 & 50 & 36 & \\
\hline & Market indicators & 37 & 39 & 45 & Cyprus \\
\hline & Business experience & 54 & 45 & 42 & \\
\hline \multirow{2}{*}{ 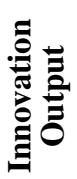 } & $\begin{array}{l}\text { Knowledge and results of } \\
\text { scientific research }\end{array}$ & 43 & 36 & 39 & $\begin{array}{l}\text { Cyprus, } \\
\text { Ukraine }\end{array}$ \\
\hline & Creativity & 38 & 26 & 38 & \\
\hline
\end{tabular}

Source: made by the authors according to the The Global Innovation Index 2017, The Global Innovation Index 2018, The Global Innovation Index 2019 
DETERMINANTS OF THE NATIONAL INNOVATION SYSTEMS' COMPETITIVENESS

OF THE EU COUNTRIES AND UKRAINE IN THE CONDITIONS OF GLOBAL TRANSFORMATIONS

Table 8

DETERMINANTS OF INNOVATIVE DEVELOPMENT OF THE COUNTRIES OF THE SUBGROUP "INNOVATIVE PERIPHERY" IN THE COORDINATES OF THE EUROPEAN INNOVATION SCOREBOARD

\begin{tabular}{|l|c|c|c|c|}
\hline \multirow{2}{*}{ GII index sub-indexes } & \multicolumn{2}{|c|}{$\begin{array}{c}\text { Average value for the countries- } \\
\text { representatives of the } \\
\text { "Innovation Centre" }\end{array}$} & $\begin{array}{c}\text { For which country is the } \\
\text { most important }\end{array}$ \\
\cline { 2 - 5 } & $\mathbf{2 0 1 7}$ & $\mathbf{2 0 1 8}$ & $\mathbf{2 0 1 9}$ & \\
\hline Impact on sales & 48 & 50 & 66 & \\
\hline Impact on employment & 69 & 73 & 80 & \\
\hline Intellectual assets & 63 & 60 & 56 & \\
\hline $\begin{array}{l}\text { Communications and } \\
\text { Entrepreneurship }\end{array}$ & 42 & 54 & 57 & Greece \\
\hline Innovators & 76 & 76 & 95 & Greece, Portugal \\
\hline Company investments & 62 & 63 & 78 & \\
\hline Funding and support & 49 & 44 & 42 & \\
\hline $\begin{array}{l}\text { Favourable environment for } \\
\text { innovation }\end{array}$ & 61 & 75 & 97 & Portugal \\
\hline Attractiveness of research systems & 86 & 91 & 80 & Cyprus \\
\hline Human resources & 94 & 108 & 103 & Cyprus, Ukraine \\
\hline The total value of the EIS index & $\mathbf{6 4}$ & $\mathbf{6 6}$ & $\mathbf{7 3}$ & \\
\hline
\end{tabular}

Source: made by the authors according to the European Innovation Scoreboard 2017, European Innovation Scoreboard 2018, European Innovation Scoreboard 2019

The sub-indices "Attractiveness of Research Systems" as well as "Human Resources" were the most important for Cyprus $\left(16^{\text {th }}\right.$ place among EU countries according to the EIS index). For Portugal (13 ${ }^{\text {th }}$ among EU countries), the sub-indices "Favourable Environment for Innovation" and "Innovators" make the largest contribution to the overall ranking.

A comparative analysis of these subgroups of countries revealed the determinants of the success of innovation in the economic systems of the EU and Ukraine. The analysis identifies the sub-indices that have the greatest impact on the overall value of the index and therefore - on the level of innovation and international competitiveness of each subgroup of countries. Namely:

For subgroup $A$, these are institutions, human capital and research, communications and entrepreneurship, favourable of environment for innovation, the attractiveness of research systems and human resources.

For subgroup $B-$ institutions, knowledge and research results, creativity, impact on employment, favourable environment for innovation, attractiveness of research systems, human resources.

For subgroup $C$ - institutions, human capital and research, creativity, innovators, a favourable environment for innovation, the attractiveness of research systems and human resources. 


\section{Conclusions}

Determinants and trends of innovation of the European economy at the preparatory, organizational, economic and developmental stages are formed by the systemic influence of a number of scientific and technological, organizational and economic, environmental, social and cultural and political factors. Modern European innovation space is characterized by inter-country and intra-regional uneven concentration of intellectual capital, different rates of technological modernization of economies, which is reflected in the scale and quality of exports and imports of goods and services, international investment activity, economic growth and competitiveness in general. It has a pronounced six-cluster centre-peripheral structure, which was confirmed by econometric analysis performed using neural instruments.

The sectoral policy of the European Union in the field of innovation, focused on the integration of NIS of member countries, is implemented in stages through the development and implementation of targeted strategies, framework agreements, joint programs, macro- and micro-projects using supranational organizational and economic resources. In the context of aggravation of global competition in the field of innovation, priorities should be determined in line with the concept of open innovation, which provides constant generation and circulation of knowledge and information through cooperation between government, research and educational organizations, large and small businesses and non-profits institutions, therefore European innovation ecosystem is being formed.

A critical condition for the effectiveness of Ukraine's modern innovation strategy is its European integration compatibility, and in the midterm the transition from the fifth to the fourth European cluster, which will provide conditions for further scientific and technological progress of systemic modernization of the national economy. State innovation policy, taking into account the analogues of EU member states, should focus on direct integration of science, education and business, development and funding of fundamental research in accordance with technological specialization, domestic and international openness and networking, which provide the correction of the legislative format of NIS.

\section{References}

1. Analytical platform "Deductor". URL: https://basegroup.ru/deductor/ description

2. Bernal J. The Social Function of Science. London : Faber \& Faber. 2010. 530 p.

3. Bush $V$. Science - the Endless Frontier. A Report to the President. United States Government Printing Office, Washington, July 1945. URL: https: / / www.nsf.gov / od / lpa/nsf50/vbush1945.htm

4. European Innovation Scoreboard 2017. European Comission, 2017. URL: https://ec.europa.eu/docsroom/documents / 24829 
DETERMINANTS OF THE NATIONAL INNOVATION SYSTEMS' COMPETITIVENESS

OF THE EU COUNTRIES AND UKRAINE IN THE CONDITIONS OF GLOBAL TRANSFORMATIONS

5. European Innovation Scoreboard 2018. European Comission, 2018. URL: https: / / op.europa.eu / en / publication-detail/-/publication /8e458033-74fc11e8-9483-01aa75ed71a1 / language-en / format-PDF / source-99539237

6. European Innovation Scoreboard 2019. European Comission, 2019. URL: https: / / ec.europa.eu/docsroom/documents /38781

7. European Innovation Scoreboard. URL: https://ec.europa.eu/growth/ industry / policy /innovation/scoreboards_en

8. Freeman C. Technology and Economic Performance: Lessons from Japan. London : Frances Pinter, 1987. 155 p.

9. Freeman $C$. The National System of Innovation in Historical Perspective. Cambridge Journal of Economics. 1995. Vol. 19. P. 5-24.

10. Glazev $S$. Yu. Teoriya dolgosrochnogo tehniko-ekonomicheskogo razvitiya. Moskva: VlaDar, 1993. [In Russian].

11. Hall A., Sulaiman R., Clark N., Yoganand B. From measuring impact to learning institutional lessons: An innovation systems perspective on improving the management of international agricultural research. Agricultural Systems. 2003. Vol. 78. P. 213-241.

12. Lundvall B. National Systems of Innovation. Towards a Theory of Innovation and Interactive Learning, London : Pinter Publishers, 1992. 317 p.

13. Metcalfe $J$. Evolutionary Economics and Technology Policy. Economic Journal. 1994. Vol. 104. P. 931-944.

14. Nelson $R$. National Innovation Systems: A Comparative Analysis. New York : Oxford University Press. 1993. 560 p.

15. Porter, M. Mezhdunarodnaia konkurentsyia: konkurentnыe preymushchestva stran. Alpyna Pablysher, 1993. [In Russian].

16. Skalatskyi $V . M$. Informatsiine suspilstvo: suchasni teorii ta modeli (sotsialno-filosofskyi analiz). 2006. URL: http://disser. com. ua/contents /7365. html7365.html. [In Ukrainian].

17. The Global Innovation Index 2017: Innovation feeding the world. Ithaca, Fontainebleau and Geneva: Cornell University, INSEAD and WIPO, 2017. URL: https://www.wipo.int/edocs/pubdocs / en /wipo_pub_gii_2017.pdf

18. The Global Innovation Index 2018: Energizing the world with innovation. Ithaca, Fontainebleau and Geneva: Cornell University, INSEAD and WIPO, 2018. URL: https: / / www.wipo.int/edocs / pubdocs / en/wipo_pub_gii_2018.pdf

19. The Global Innovation Index 2019: Creating healthy lives - the future of medical innovation. Ithaca, Fontainebleau and Geneva: Cornell University, INSEAD and WIPO, 2019. URL: https: / / www.wipo.int/edocs/pubdocs / en / wipo_pub_gii_2019.pdf

20. The Global Innovation Index. URL: https://www.globalinnovationindex. org Home

21. World Bank official statistics service. URL: https:/ / data.worldbank.org/

The article was submitted for publication on March 25, 2021. 